\title{
Preliminary pedogeochemical and biogeochemical studies on the Hinota kimberlite, Panna District, MP
}

\author{
S M MATHUR and P O ALEXANDER* \\ Centre of Advanced Study in Geology, University of Saugar, Sagar 470 003, India \\ * Department of Applied Geology
}

MS received 17 October 1980: revised 20 August 1982

\begin{abstract}
Distribution of a number of trace elements in the Hinota kimberlite pipe, its overlying soil and selected vegetation is discussed in relation to the distribution of the same elements in the soils and vegetation overlying the quartzite country rock through which it is emplaced. The values of most elements in Hinota are similar to those of kimberlites from some other parts of the world, but $\mathrm{Ni}$ and $\mathrm{Cu}$ are higher. These elements in a "floating reef" of the Dhandraul Quartzite in the pipe closely follow the averages for other sandstones. It is observed that most elements in the soil over the kimberlite are significantly higher than in the soil over the surrounding country rock, particularly $\mathrm{Ni}, \mathrm{V}, \mathrm{Cu}$ and $\mathrm{Cr}$. These could serve as reasonable guides to prospecting for kimberlites. Trace elements in the ash of selected trees growing over the diatreme and the country rock do not show any significant differences.
\end{abstract}

Keywords. Hinota kimberlite; trace elements; pedogeochemistry; biogeochemistry.

\section{Introduction}

Pedogeochemical and biogeochemical methods of prospecting have already proved useful in several cases of mineral exploration. Such studies have also been effectively used in India, particularly for tracing the extension of some known base metal mineralised belts, potential mineralised zones and around areas of non-favourable geological regions (Bose and Banerjee 1976). However, these studies for prospecting of hidden kimberlite pipes have not been carried out so far in our country, and only at a few places elsewhere. Accounts of geochemical prospecting for kimberlites in general are also not common. Applied geochemical studies in the Katanga area (Van de Steen 1961) and kimberlite pipe near Kenieba, West Africa (Aicard 1959), however, have yielded encouraging results. Theoretically, emplacement of kimberlite diatremes (which have rather unusual chemistry with specifically high concentrations of $\mathrm{Cr}, \mathrm{Ni}$, $\mathrm{Co}, \mathrm{Cu}$ ) in the country rocks of the cratonic areas should be in geochemical contrast in respect of these trace elements. Buried kimberlite diatremes could therefore possibly be located by detailed pedogeochemical and biogeochemical surveys provided such studies yield positive correlation in the already known areas of kimberlite occurrences. The aim of this paper is to explore such a possibility. Trace element distributions in kimberlite, the soil cover and three of the common occurring plants over it are reported for the Hinota diatreme, Panna District, MP (figure 1). The choice of the Hinota pipe was obvious as it is more or less in its natural state and the surface soil has not been generally disturbed. The results therefore are expected to be unbiased unlike they would be in the case of the Majhgawan diatreme, situated about $3 \mathrm{~km}$ southeast, which has been extensively churned over by old and recent workings. 


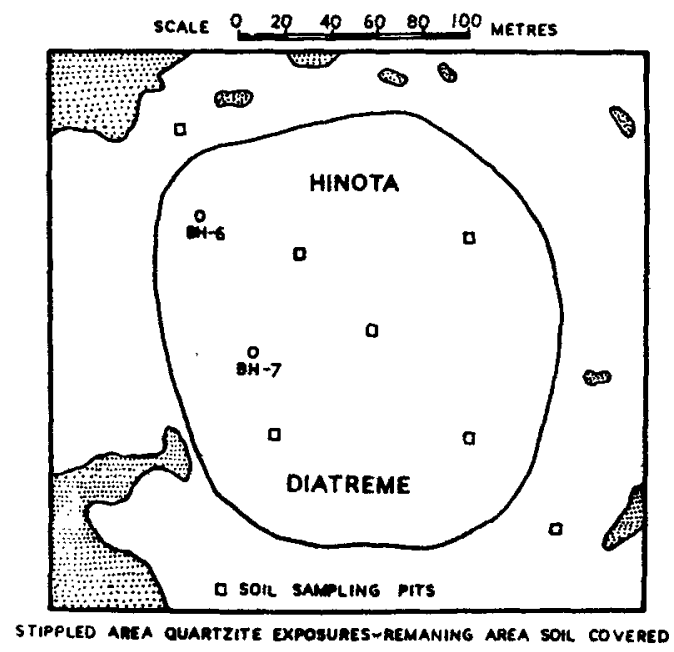

Figure 1. Simplified plan of Hinota diatreme.

Table 1. Selected trace elements in the Hinota and some other kimberlites (all values in ppm).

\begin{tabular}{|c|c|c|c|c|c|c|}
\hline & \multicolumn{3}{|c|}{ Hinota } & \multirow{2}{*}{$\begin{array}{c}\text { Basutoland } \\
\text { (Dawson 1962) }\end{array}$} & \multirow{2}{*}{$\begin{array}{c}\text { Yakutia } \\
\text { Litinski 1961) }\end{array}$} & \multirow{2}{*}{$\begin{array}{l}\text { South-West } \\
\text { Africa } \\
\text { (Jones 1964) }\end{array}$} \\
\hline & $\begin{array}{c}\text { Borehole } \\
\text { No. } 6\end{array}$ & $\begin{array}{c}\text { Borehole } \\
\text { No. } 7\end{array}$ & Surface & & & \\
\hline $\mathrm{Ni}$ & $285-750$ & $65-500$ & $<500$ & 1140 & 450 & 1200 \\
\hline $\mathrm{Co}$ & $50-90$ & $25-90$ & 10 & 77 & 40 & $\cdot 50$ \\
\hline $\mathrm{Cu}$ & $150-200$ & $50-200$ & 5 & 100 & 60 & - \\
\hline $\mathrm{Pb}$ & 25 & $10-25$ & 10 & 9 & - & 30 \\
\hline $\mathrm{Ga}$ & $10-50$ & $10-25$ & 5 & 9 & - & 10 \\
\hline V & $100-150$ & $50-200$ & 10 & 120 & 170 & 160 \\
\hline $\mathrm{Cr}$ & - & - & $<500$ & 1440 & 1500 & 1000 \\
\hline $\mathbf{B a}$ & - & - & 10 & 740 & - & 1000 \\
\hline
\end{tabular}

Analyses of the Hinota samples by the Geological Survey of India.

The Hinota kimberlite diatreme is not economic for diamond production unlike the Majhgawan diatreme which sustains a regular production of about 10,000 carats per annum. Extensive petrological, mineralogical, geochemical and geochronological studies have been carried out on the Hinota diatreme (Kresten and Paul 1976; Paul 1979; Paul et al 1975a, b, 1976, 1977). This paper embodies the results of some selected trace element data on the kimberlite by one of the authors together with trace element analyses on the soils and selected vegetation in and around the diatreme acquired by the late Dr D R Grantham (who passed on his papers to one of the authors before his death). The results are shown in tables 1 to 4 . For comparison trace element data of some other kimberlites are also given in table 1 . 
emplaced, a "floating reef" of this rock within the pipe body encountered in borehole No. 7 has been analysed. These data are presented in table 2. Five samples of the "reef" have given the same values showing the highly consistent concentration of these elements in the quartz arenite. For comparison, trace element data of a Vindhyan sandstone (possibly Rewah) at Sagar of similar petrology and chemistry and the averages of a large number of sandstones (Hawkes and Webb 1962) are also recorded. This "floating reef" of quartzite, though only about $10 \mathrm{~m}$ thick and not as huge as the Waterberg Quartzite occurring in the Premier pipe (South Africa), presents interesting implications. It is observed that most of the elements ( $\mathrm{Ni}, \mathrm{Co}, \mathrm{Cu}$ and $\mathrm{V}$ ) in the Hinota "reef" are within the usual range of these elements found in other normal sandstones. Cobalt, however, has a slightly higher value. How far is this difference real and meaningful can only be assessed when its concentration in the surrounding Dhandraul Quartzite is known. On the whole it implies that the kimberlitic magma seemingly had no effect on the caught-up quartz arenite in modifying the trace element chemistry of the refractory quartzite so far as these elements are concerned. A comparison of the kimberlite and sandstone analyses in tables 1 and 2 shows that most of the elements are enriched several times in the kimberlite as compared to the sandstone of the country rock.

\section{Pedogeochemistry}

Distribution of 11 trace elements in the samples collected over the diatreme and over the adjacent country rock of Dhandraul Quartzite is shown in table 3. Soil samples were collected from three different horizons to determine the most anomalous horizon with respect to the elements of interest. The six samples at depths of $30-90 \mathrm{~cm}$ were collected along two lines laid at right angles, crossing at a point approximately at the centre of the pipe area. The soil samples from $1.8 \mathrm{~m}$ depth and $2.4 \mathrm{~m}$ depth were collected from the side of a pit. The last sample was obtained from the soil covering the Dhandraul Quartzite about $1.5 \mathrm{~km}$ north of Panna (figure 2).

Concentrations of four elements of interest considered here namely, $\mathrm{Cr}, \mathrm{Ni}, \mathrm{V}$ and $\mathrm{Cu}$, are highly variable in the soils in general. $\mathrm{Cr}$ has a range of 5-1000, Ni 5-500, $\mathrm{Co} 1-40$ and $\mathrm{Cu} 2-100 \mathrm{ppm}$ (Levinson 1972). The average concentration of these four elements in the top soil covering the Hinota kimberlite is as follows: $\mathrm{Cr} 120, \mathrm{Ni} 56$, $\mathrm{V} 127$ and $\mathrm{Cu} 49 \mathrm{ppm}$. In contrast, the soil covering the neighbouring quartzite has the following figures for the same elements; $\mathrm{Cr} 40, \mathrm{Ni} \mathrm{30}, \mathrm{V} 30$ and $\mathrm{Cu} 10 \mathrm{ppm}$. This means that $\mathrm{Cr}, \mathrm{Ni}, \mathrm{V}$ and $\mathrm{Cu}$ are enriched $3,2,4$ and 5 times, respectively, in contrast to the soils over quartzitic rocks.

Considering the distribution of these elements in the entire soil profile, it is observed that all the elements do not have a similar pattern. $\mathrm{Cr}$ and $\mathrm{V}$ have their maximum concentrations in the deeper levels ( $2.4 \mathrm{~m}$ depth) having $180 \mathrm{ppm}$ of $\mathrm{Cr}$ and $150 \mathrm{ppm}$ of $V$. Nickel, on the other hand, has the most anomalous value in the intermediate depths of the soil profile ( $1.8 \mathrm{~m}$ depth), having a concentration of. $130 \mathrm{ppm}$ in contrast to 56 ppm in shallower depths and 120 in deeper parts. Copper and cobalt have more or less similar distribution patterns: their enrichment is found both in the shallower as well as deeper horizons. In the appraisal of the Katanga area geochemical anomalies with respect to $\mathrm{Cu}, \mathrm{Zn}, \mathrm{Sn}, \mathrm{Cr}$ and $\mathrm{Ni}$ in the soils overlying the kimberlite pipe have been found to be useful (Van de Steen 1961). Similarly, Cu and Ni anomalies at depths of 30 and $100 \mathrm{~cm}$ in soils overlying a kimberlite pipe near Kenieba, West Africa, have proved to be useful indications for prospecting hidden kimberlite pipes. Chromium, in 


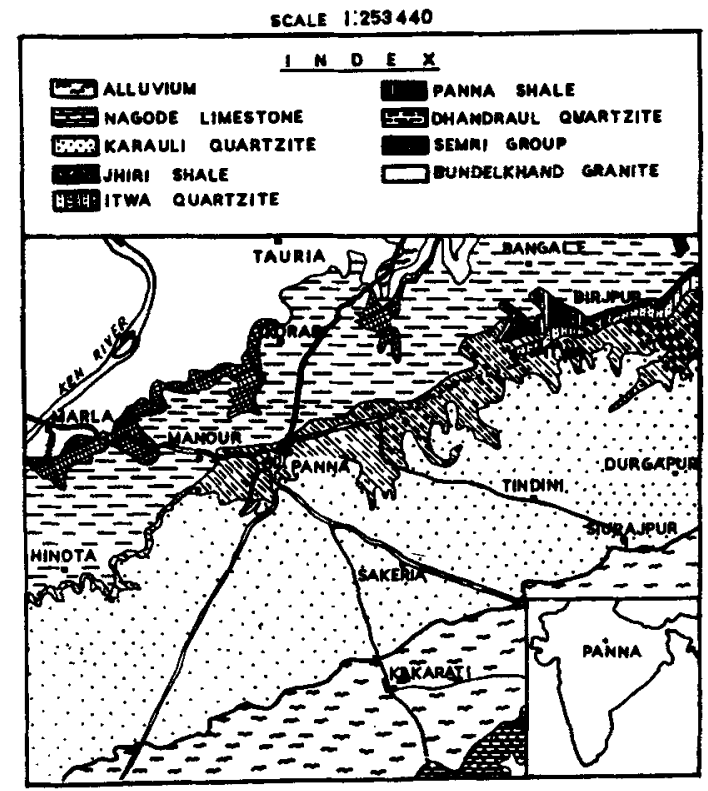

Figure 2. Part of the Panna diamond field.

particular, at a depth of $100 \mathrm{~cm}$, has a more pronounced difference than $\mathrm{Ni}$, and has been recommended specifically in aid of kimberlite prospecting (Aicard 1959) This work also proves that anomalous distributions of $\mathrm{Cr}$ and $\mathrm{V}$ at $2.4 \mathrm{~m}$ depth in the quartzitic area can be useful geochemical guides for prospecting of kimberlites. Similarly, Ni at $1.8 \mathrm{~m}$ level seems to be a good indicator for the occurrence of ultramafic rocks like kimberlite in an otherwise nickel-poor, soil-covered region derived from sandy rocks. Cu does seem to be as useful as $\mathrm{Cr}$ and $\mathrm{Ni}$ in the present case. On the other hand, $V$ has values which seem to be nearly four to five times enriched in soil over the kimberlite pipe in contrast to the general background, and could also be a useful geochemical guide in prospecting.

The soil on the kimberlite pipe area in general is of residual type but a certain amount of contribution from transported material cannot be ruled out, particularly in the depressions formed by the diatreme. Efforts should be made to test the validity of the suggested geochemical guides by a thorough study of the soil profile itself and the extent of residual and transported nature of soils to give a more realistic and meaningful interpretation.

\section{Biogeochemistry}

Biogeochemical prospecting has had very limited application so far in our country mainly because of its various variables and complications involved. However, because of greater depth of penetrations, this technique has great potential provided systematic and detailed orientation surveys are undertaken. The present findings are most preliminary in this direction and are aimed only at pointing towards more serious attempts in future for using trace element contents of plant ash as potential indicators 
appearance with very little alteration. Quartz occurs as subhedral to anhed ral independent grains $(2-3 \mathrm{~mm})$. Laths of brown, pleochroic, unresorbed biotite constitute the major mafic component. Hornblende occurs rarely and is seen at places breaking down to a granular aggregate with associated iron-oxides. Sphene and apatite are ubiquitously present as accessories. Minor amounts of secondary epidote and calcite are also observed.

The modal compositions (table 1) show that plagioclase (av. 30.91) is slightly in excess to $\mathrm{K}$-feldspar (av. 28.85). Moderately high amount of accessories (av. 13.64) is also characteristic.

The mafic enclaves within the granite are inhomogeneous having an abundance of hornblende with subordinate biotite, epidote, sphene, feldspars, little quartz and iron oxide. Appreciable amount of apatite is also noted. Locally, the hornblende is partially altered to biotite, which in turn shows conversion to chlorite and granular snhene.

\section{Geochemistry}

Major element composition of six representative samples from the granite and one from the enclave are presented in table 2 and the normative compositions are given in table 3. Major elements were analysed by conventional wet methods and trace elements by atomic absorption spectrophotometer (Perkin-Elmer 4000). $\mathrm{Na}$ and $\mathrm{K}$ were analysed by flame photometer.

Among the major elements, $\mathrm{SiO}_{2}$ and $\mathrm{Al}_{2} \mathrm{O}_{3}$ values indicate a granitic to granodioritic nature. $\mathrm{Na}_{2} \mathrm{O}$ generally exceeds $\mathrm{K}_{2} \mathrm{O}$ which is characteristic of this granite in contrast to the higher $\mathrm{K}_{2} \mathrm{O}$ and consistently higher $\mathrm{K}_{2} \mathrm{O} / \mathrm{Na}_{2} \mathrm{O}$ ratios for the other magmatic granites of Kerala ( $c f$. Santosh and Nair 1983). Based on $\mathrm{K}_{2} \mathrm{O}$ versus $\mathrm{Na}_{2} \mathrm{O}$ values (Harpum 1963), the rock type is chemically classified as granodiorite (figure 2).

$\mathrm{Al}_{2} \mathrm{O}_{3}$ levels of the granite are generally high, ranging from 15.3 to 16.83 . Since the molecular proportion, $\mathrm{Al}_{2} \mathrm{O}_{3} /\left(\mathrm{CaO}+\mathrm{Na}_{2} \mathrm{O}+\mathrm{K}_{2} \mathrm{O}\right)$ is greater than unity, the granite could be considered as peraluminous (Clarke 1981) but not essentially an S-type (White and Chappell 1977) since characteristic aluminous minerals like garnet or a luminium silicates are lacking. $\mathrm{FeO} / \mathrm{MgO}, \mathrm{Na}_{2} \mathrm{O} / \mathrm{CaO}$ and $\mathrm{K}_{2} \mathrm{O} / \mathrm{CaO}$ ratios are generally high, typical of magmatic granites. $\mathrm{Fe}_{2} \mathrm{O}_{3} / \mathrm{CaO}$ values are also high and might indicate considerable water vapour pressure during crystallization.

Harker variations of the major elements are shown in figure 3. The sharp depletion of $\mathrm{Al}_{2} \mathrm{O}_{3}$ and $\mathrm{K}_{2} \mathrm{O}$ are consistent with crystallization of $\mathrm{K}$-feldspar which, as seen from petrography, was a principal fractionating phase. $\mathrm{Na}_{2} \mathrm{O}$ shows rather scattered plots.

Table 1. Modal composition of Kalpatta granite.

\begin{tabular}{lrrrrrr}
\hline & KA-1 & KA-2 & KA-3 & KA-4 & KA-7 & KA-9 \\
\hline Quartz & 28.68 & 25.34 & 23.09 & 27.77 & 26.05 & 27.71 \\
Kufeldspar & 28.28 & 29.52 & 31.16 & 29.66 & 28.47 & 26.03 \\
$\begin{array}{l}\text { Plagioclase } \\
\text { Biotite }\end{array}$ & 30.22 & 32.98 & 30.09 & 29.44 & 30.28 & 33.44 \\
$\begin{array}{l}\text { Hornblende. } \\
\begin{array}{l}\text { Sphene, Apatite } \\
\text { and athors }\end{array}\end{array}$ & 5.32 & 5.68 & 6.97 & 5.39 & 6.03 & 4.61 \\
& 7.50 & 6.48 & 8.69 & 7.74 & 9.17 & 8.21 \\
\hline
\end{tabular}


Table 2. Major element analyses of Kalpatta granite and 'Enclave' rock

\begin{tabular}{lrrrrrrr}
\hline $\mathrm{Wt} \%$ & KA-1 & KA-2 & KA-3 & KA-4 & KA-7 & KA-9 & KA-10 \\
\hline $\mathrm{SiO}_{2}$ & 73.94 & 72.32 & 69.47 & 73.79 & 72.19 & 74.38 & 55.52 \\
$\mathrm{Al}_{2} \mathrm{O}_{3}$ & 15.30 & 15.30 & -16.83 & 15.81 & 15.81 & 15.30 & 17.34 \\
$\mathrm{TiO}_{2}$ & 0.12 & 0.14 & 0.39 & 0.09 & 0.21 & 0.08 & 0.47 \\
$\mathrm{FeO}$ & 0.68 & 0.81 & 1.35 & 0.32 & 1.44 & 0.45 & 2.05 \\
$\mathrm{Fe}_{2} \mathrm{O}_{3}$ & 0.11 & 0.70 & 1.06 & 0.68 & 0.80 & 0.62 & 6.75 \\
$\mathrm{CaO}_{\mathrm{MgO}}$ & 1.35 & 1.79 & 2.02 & 1.57 & 2.02 & 1.79 & 8.30 \\
$\mathrm{Na}_{2} \mathrm{O}$ & 0.48 & 0.48 & 0.81 & 0.16 & 0.65 & 0.16 & 3.23 \\
$\mathrm{~K}_{2} \mathrm{O}$ & 4.02 & 4.83 & 4.17 & 4.07 & 3.99 & 4.27 & 4.12 \\
$\mathrm{MnO}$ (ppm) & 2.93 & 3.49 & 3.63 & 3.05 & 2.88 & 2.54 & 0.67 \\
$\mathrm{P}_{2} \mathrm{O}_{5}$ (ppm) & 234 & 160 & 208 & 122 & 227 & 105 & 107 \\
L.O.I. & 526 & 458 & $0.13 \%$ & 32 & 549 & 18 & $0.26 \%$ \\
$\mathrm{Moisture}$ & 0.18 & 0.22 & 0.25 & 0.11 & 0.18 & 0.11 & 0.49 \\
\hline
\end{tabular}

KA-1 to KA-9 Kalpatta Granite; KA-10 - 'Enclave' rock.

Table 3. Normative composition of Kalpatta granite

\begin{tabular}{|c|c|c|c|c|c|c|c|}
\hline & & KA-1 & KA-2 & KA-3 & $\mathrm{KA}-4$ & KA-7 & KA-9 \\
\hline $\mathbf{Q}$ & & 34.68 & 24.96 & 24.66 & 34.74 & 31.49 & 35.23 \\
\hline Or & & 17.24 & 20.57 & 21.68 & 17.79 & 17.24 & 15.01 \\
\hline $\mathbf{A b}$ & & 35.91 & 42.44 & 36.64 & 35.63 & 35.11 & 37.20 \\
\hline An & & 6.67 & 8.92 & 9.17 & 7.78 & 10.01 & 8.90 \\
\hline \multirow{2}{*}{ Hy } & En & 0.79 & 1.20 & 2.00 & 0.40 & 1.60 & 0.40 \\
\hline & Fs & 1.20 & 0.66 & 0.92 & - & 1.58 & 0.13 \\
\hline Mt & & 0.23 & 0.93 & 1.62 & 0.70 & 1.16 & 0.93 \\
\hline $\mathrm{He}$ & & - & - & - & 0.15 & - & - \\
\hline 11 & & 0.32 & 0.32 & 0.80 & 0.16 & 0.48 & 0.16 \\
\hline Ap & & - & - & 0.16 & - & - & - \\
\hline C & & 2.86 & - & 2.35 & 2.75 & 2.14 & 2.04 \\
\hline
\end{tabular}

The depletion in $\mathrm{CaO}, \mathrm{MgO}, \mathrm{FeO}^{t}$ and $\mathrm{TiO}_{2}$ suggest early crystallization of mafic minerals which are ubiquitously present as accessory constituents in the granite.

The chemical composition of the mafic enclave rock shows low silica and high alumina values. $\mathrm{CaO}, \mathrm{Fe}_{2} \mathrm{O}_{3}$ and $\mathrm{MgO}$ values are very high. These are in accordance with mineralogy.

Among the trace elements (table 4), the consistently lower levels of Ba and Sr imply that the magma underwent considerable degree of feldspar fractionation. $\mathrm{Cr}$ shows high values and are in contrast to those expected in a fractionated granite, even if the melt had equilibrated from a mafic source. Moreover, these values do not correlate with $\mathrm{Ni}$, which shows lower levels. Hence it is assumed that $\mathrm{Cr}$ in the granite was contributed from the mafic supracrustals which occur as enclaves within the granite. The values of other trace elements are in general similar to those for the magmatic granites of Kerala.

Variation of trace elements are plotted against the index of differentiation, $\mathrm{Mg} / \mathrm{Mg}+\mathrm{Fe}^{\prime}$ (figure 4). $\mathrm{Li}, \mathrm{Ni}, \mathrm{Co}$ and $\mathrm{Zn}$ show depletion consistent with their 

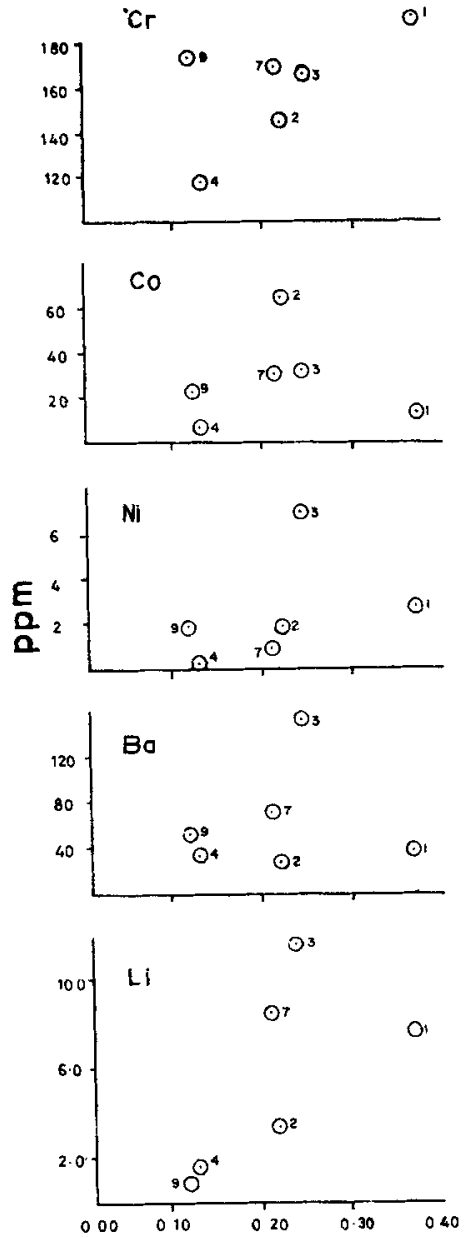

$W t \% M g / M g+\varepsilon F e$
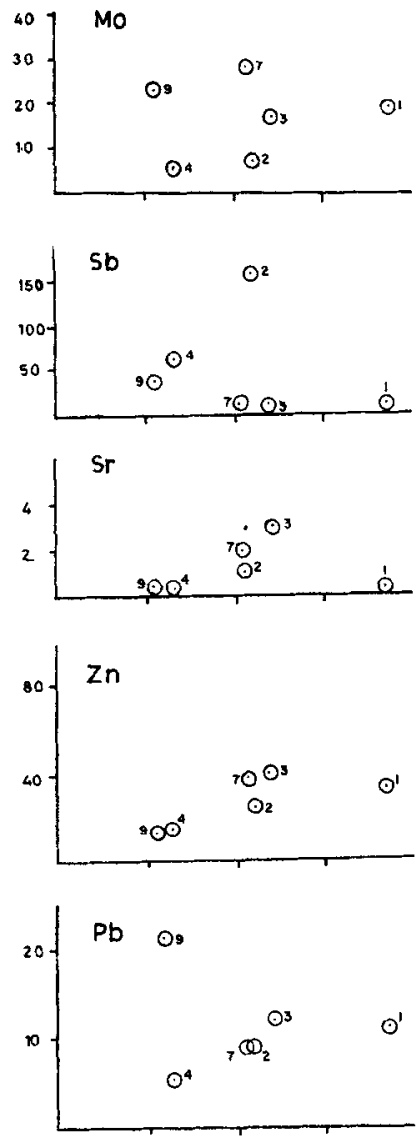

Figure 4. Trace element values vs $w t \% \mathrm{Mg} / \mathrm{Mg}+\Sigma$ Fe plots of Kalpatta granite.

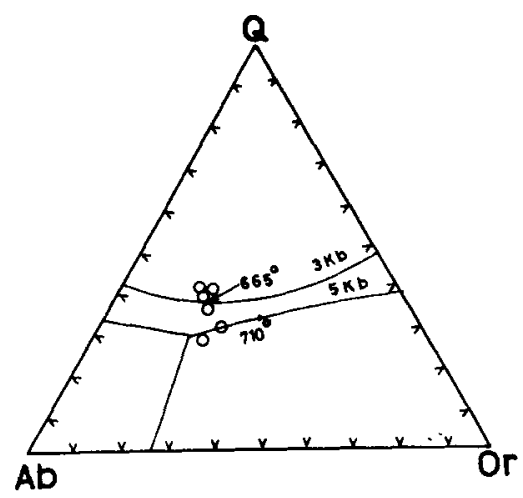

Figure 5. Polybaric diagram (after Tuttle and Bowen 1958) showing $\mathbf{Q}-\mathbf{A b}-$ Or plots of Kalpatta granite. 


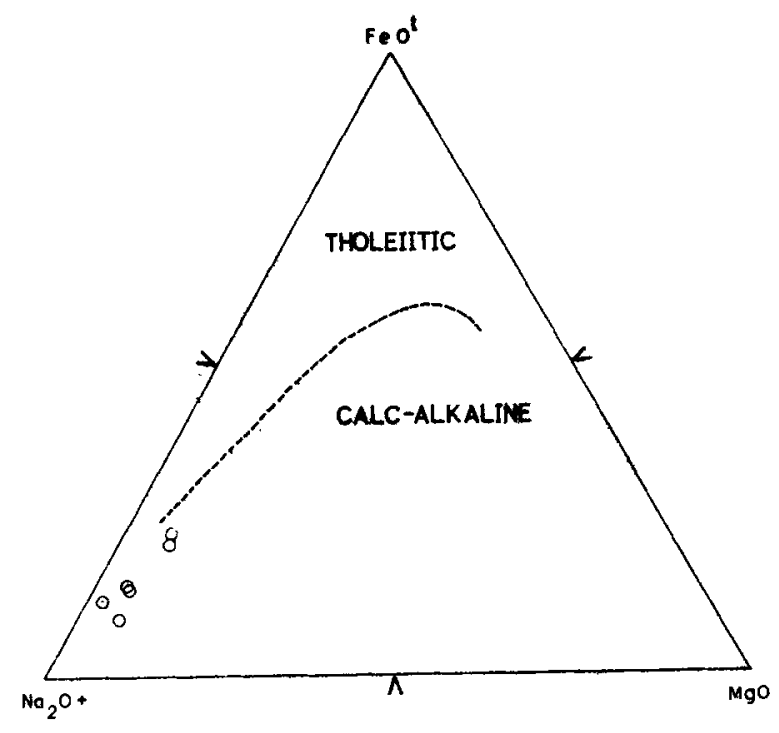

Figure 6. A-F-M plots of Kalpatta granite.

depth. The enclaves are elliptical or rounded in shape and are different from the micaceous 'restites' (Didier 1973) resulting from anatectic process. Higher levels of $\mathrm{CaO}, \mathrm{MgO}, \mathrm{FeO}^{\prime}$ and $\mathrm{Cr}$ in the granite imply that there was significant reciprocal reaction between the granite and the enclaves resulting in the addition of these elements to the former. However, complete equilibrium between the mineral phases present in the enclaves and the granite is lacking. Nevertheless, the regional distribution of accessory minerals like apatite and sphene in considerable amounts in the granite (table 1) support the evidence of contamination. The apatite concentration in the enclaves is in accordance with the view of Nockolds (1935) that volatiles play a significant role in the mutual transfer of elements. Experimental deduction of Luth et al (1964) that vapour-phase transfer of alkalies could modify a metaluminous granitic liquid to peraluminous may be applied in the present case. Accordingly, the subsolvus nature is also in support of such mass transfer. Plots in an A-F-M diagram (figure 6) show a calc-alkaline trend, indicating a progressive decrease in the $f_{2} o_{2}$ regimes during the course of crystallization.

The elliptical shape of the granite body, its intrusive relationship with the country rocks, presence of enclaves and absence of significant replacement textures along with geochemical characters assign a magmatic parentage for the Kalpatta granite. Petrochemistry suggests that the granite was derived by feldspar and quartz fractionation from a parent magma, probably generated by partial melting at deeper crustal levels with subsequent supracrustal contamination.

\section{Acknowledgements}

The study forms part of CESS project "Acid magmatism and related metallogeny in Kerala". The authors are grateful to Prof. C Karunakaran for facilities. 


\section{References}

Clarke D B 1981 Can. Mineral. 193

Didier I 1973 Granites and their enclaves (Amsterdam: Elsevier), p. 393

Harpum J R 1963 Rec. Geol. Surv. Tanganyika 1080

Luth W C, Jahns R H and Tuttle O F 1964 J. Geophys. Res. 69759

Marmo V 1971 Granite petrology and the granite problem (Amsterdam: Elsevier), p. 244

Nair M M and Vidyadharan K T $1982 \mathrm{~J}$. Geol. Soc, India 2346

Nair P K R 1976 Curr. Sci. 45379

Nair P K R 1977 Curr. Sci. 46266

Nockolds S R 1935 Geol. Mag. 72289

Santosh M and Nair N G K $1983 \mathrm{~J}$. Geol. Soc. India (in press)

Soman K. Nair N G K, Golubyev V N and Arakelyan M M 1982 J. Geol. Soc. India 23458

Tuttle O F 1955 Colloq. Internat. Centre Natl. Rech. Sci. (Nancy)

Tuttle O F and Bowen N L 1958 Geol. Soc. Am. Mem. 141

White A J R and Chappell B W 1977 Tectonophysics 437 